\title{
SEROLOGICAL DIAGNOSIS OF BOVINE CORONAVIRUS IN CALVES USING A DEVELOPMENT NATIVE ELISA PREPARATION
}

\author{
RANIA S. EL-MOHAMADY \\ Viral Diseases Research Unit, Animal Reproduction Research Institute (ARRI), \\ Agricultural Research Center (ARC), Giza, Egypt.
}

Received: 31 December 2020; Accepted: 15 March 2021

\begin{abstract}
Bovine coronavirus $(\mathrm{BCoV})$ infection has found worldwide among cattle of all ages, causing diarrhea in newborn calves, winter dysentery in adult cattle and respiratory tract diseases results in major economic losses in dairy herds. The objective of this study was to establish an ELISA kits as patent prepared in Lab. with assessment its applicability in the field samples. Sixty-five pneumonic calves 2- to 4-month-old, used in this study to detect BCoV antibodies in serum of infected calves, where it assayed against $\mathrm{BCoV}$ antibodies by using prepared ELISA plates and SNT. The results were positive for BCoV antibody $72.3 \%$ and $53.9 \%$ by ELISA and SNT respectively. The prepared ELISA showed high sensitivity of over SNT, where sensitivity, specificity and correlation were $91.4 \%, 50 \%$ and $72.3 \%$ respectively, and there is a positive correlation between both tests. The test has been successfully used in longitudinal field studies on virus dynamics and evaluation of management routines. In conclusion the patent prepared ELISA is more sensitive, accurate and specific assay than SNT for detection of $\mathrm{BCoV}$ antibodies, in addition to saving time and commercial kits cost.
\end{abstract}

Keywords: $\mathrm{BCoV}$ - newborn calves- ELISA - SNT - respiratory manifestations.

\section{INTRODUCTION}

In the dairy industry worldwide, bovine coronavirus $(\mathrm{BCoV})$ is a widely spread pathogen causing disease and economic losses. The prevention of the spread of viruses is hampered by a lack of basic awareness of the potential for viral shedding and transmission in individual animals (Oma et al., 2016; Johnson and Pendell, 2017 and Amer, 2019). BCoV has been associated with gastrointestinal and

Corresponding author: RANIAS.EL-MOHAMADY E-mail address: rania.elmohamdy@arc.sci.eg Present address: Viral Diseases Research Unit, Animal Reproduction Research Institute (ARRI), Agricultural Research Center (ARC), Giza, Egypt. respiratory diseases in cattle including diarrhea in neonatal calves, winter dysentery and respiratory tract illness (Storz et al., 2000). In dairy and beef calves, $\mathrm{BCoV}$ can cause enteritis in healthy and diarrheal calves, $\mathrm{BCoV}$ can often be identified, that complicating the assessment of its role as a primary pathogen (Bartels $e t$ al., 2010).

$\mathrm{BCoV}$ may be life threatening, due to loss of electrolytes and malnutrition (Francoz et al., 2015). BCoV infects the upper, lower respiratory tract and intestine also, It is not unexpected that cattle would have a coronavirus with tropism for the respiratory tract. Coronaviruses infect the respiratory tract of other species including pigs, turkeys, and chickens. Thus, this virus 
has a role in both respiratory tract disease and enteric diseases (Fulton, 2009). Subsequently, BCoV was also associated with the occurrence of respiratory distress in calves and adults (Lathrop et al., 2002).

The respiratory syndrome is often observed during or after transportation because the shipping of cattle represents a stressing factor that may facilitate the onset of $\mathrm{BCoV}$ induced respiratory disease, mainly in calves (Decaro et al., 2008). Ohlson et al., (2010b) recorded nasal shedding within a herd form respiratory $\mathrm{BCoV}$ clinical or subclinical infected calves and young adult cattle. Gomez et al. (2017) observed shedding of $\mathrm{BCoV}$ in the absence of other important respiratory tract pathogens in cattle with naturally occurring BRD.

$\mathrm{BCoV}$ is consist of a single stranded, nonsegmented positive sense genomic RNA, 32 $\mathrm{kb}$ long. It belongs to the Beta coronavirus genus cluster within the Coronavirinae subfamily, Coronaviridae family, and the order Nidovirales (http://ictvonline.org/ virusTaxonomy.asp). (Hasoksuz et al., 2008). BCoV possesses five major structural proteins have various functions in the viral cycle. Which spike (S), hemagglutinin/esterase (HE), nucleocapsid $(\mathrm{N})$, transmembrane $(\mathrm{M})$ and the small membrane (E) (Lai and Cavanagh, 1997). The $S$ protein is responsible for the interaction between the virus and the cellular receptor eliciting antibodies with high neutralizing efficacy in its host (Yoo and Deregt, 2001). BCoV consists of one serotype with some antigenic variation between different strains. Acutely infected animals produce long-lasting antibodies, probably for many years (Lin et al., 2002).

The seroprevalence of anti-BCoV antibodies among newborn calves ranged from 20\% (17/82) in Algeria (Ammar et $a l ., 2014)$ to $93.9 \%(172 / 183)$ in Turkey (Yavru et al., 2018). Molecular detection of the virus by qRT-PCR was reported from several countries leading to variable prevalences. Recently, the occurrence of $\mathrm{BCoV}$ in neonatal calf was estimated to $7.2 \%(14 / 194)$ in Iran using antigencapture ELISA (Lotfollahzadeh et al., 2020).

The importance of good colostrum management, leading to an adequate passive transfer in the prevention of calf diarrhea is without debate (Dunn et al., 2017). It is unclear if vaccinating cows late in gestation improves calf antibody titers or whether the practice improves resistance of calves to disease. To provide optimal immunity, vaccine antigens should be as similar as possible to the circulating strains. Therefore, future studies should focus on epidemiological surveillance in order to avoid potential causes of vaccination failure (Mihai et al., 2006).

Rapid and reliable diagnostic methods are the primary prerequisite for timely and effective implementation of therapeutic and preventive measures (Reschová et al., 2001). The diagnosis of $\mathrm{BCoV}$ can be achieved using viral culture, antigencapture ELISA, hemagglutination assay using mouse erythrocytes, and PCR (Boileau and Kapil, 2010).

The enzyme linked immunosorbant assay (ELISA) for antibody detection is fast, simple and precise method for screening large numbers of tested samples (Nylin et al., 2000). The BCoV commercial ELISA kits is so expensive and not always available, so the objective of this study was to establish an ELISA kits for $\mathrm{BCoV}$ antibody detection as a patent prepared in Lab. with assessment its sensitivity and applicability in the field samples.

\section{MATERIALS AND METHODS}

\section{Clinical samples:}

Sixty-five pneumonic calves 2- to 4-monthold were included in this study. These calves were carefully examined and excluded other agents that cause respiratory 
manifestation. Blood samples were taken into sterile vacuum tubes collected for serological testing were brought into laboratory under cold chain and centrifuged at $720 \mathrm{xg}$ for 15 minutes and taken into sterile eppendorf tubes. Serum samples inactivated in $\left(56^{\circ} \mathrm{C}, 30 \mathrm{~min}\right)$ then kept at $80^{\circ} \mathrm{C}$ until testing.

\section{Virus and cell culture:}

Madin Darby bovine kidney (MDBK) cells tested against latent infection with mycoplasma and bovine viral diarrhea virus were supplied by National Animal Disease Center, Ames Iowa, USA. Eagle's minimum essential medium (EMEM; Gibco BRL, life technologies, Scotland, UK) supplemented with Fetal bovine serum (FBS) was obtained from Sigma, Chemical CO.USA.A commercial antibiotic/ antimycotic mixture (Sigma, Chemical CO. USA). An international Mebus reference strain was used as tested antigen all over the study.

\section{Quantitation of the virus:}

After serial passage of the virus in MDBK cells, the tissue culture infected dose 50 (TCID 50 ) was calculated according to (Reed and Muench, 1938) method.

\section{Virus concentration by polyethylene glycol-6000 (PEG-6000) precipitation:}

Virus concentration was done as illustrated in Mahy and Kangro (1996). At complete cytopathic effect (CPE), the cells and medium are harvested by scraping with a rubber policeman. Multiple cycles of freeze-thawing can effectively break up the cells. The pooled harvest was clarified by centrifugation at $5000 \mathrm{xg}$ for 5 minutes. To the supernatant and at a final volume slowly add 2.3\% NaCI and 7.0\% PEG-6000 with constant and gentle stirring. Cover the beaker and stir for about $1 \mathrm{~h}$ more to ensure complete solubilization of the PEG. Transfer the beaker and ice bath to a refrigerator, and allow the virus and other proteins to precipitate overnight at $4^{\circ} \mathrm{C}$. In the next day, the precipitate was collected by centrifugation at $10000 \mathrm{xg}$ for 10 minutes in cooling centrifuge. To the precipitate, $3 \mathrm{ml}$ of TES buffer (0.01 M Tris-HCI, $\mathrm{pH}$ 7.2, $0.002 \mathrm{M}$ EDTA, $0.15 \mathrm{M} \mathrm{NaCI}$ ) was added and the precipitate was thoroughly suspended. Finally, the PEG is removed (pelleted) by centrifugation of this pooled suspension at 13,000 $\mathrm{xg}$ for $4 \mathrm{~min}$ and the supernatant contains the concentrated virus in isotonic TES buffer was collected.

\section{Estimation of antigen concentration:}

Antigen concentration was determined as in Bradford (1976). A mixture of $100 \mu \mathrm{l}$ of antigen and $5 \mathrm{ml}$ of reagent $(100 \mathrm{mg}$ coomassie brilliant blue G-250, $50 \mathrm{ml}$ absolute ethanol, $100 \mathrm{ml}$ orthophosphoric acid $85 \%$ and water to 1 liter was incubated for minutes before reading the absorbance in spectrophotometer at wave length $595 \mathrm{~nm}$. A stander curve was made using bovine serum albumin. (He, 2011).

\section{Enzyme linked immunosorbant assay (ELISA):}

At antigen concentration $8 \mu \mathrm{g} / \mathrm{well}$, ELISA plates (Nune immune-11 96wells) were coated at $4^{\circ} \mathrm{C}$ overnight with coating buffer (1.59 gm $\mathrm{NaCo}_{3}$ and $2.9 \mathrm{gm} \mathrm{NaHCo}_{3}$ per $1000 \mathrm{ml}$ deionized water. The upper two left well will act as blank and the next three one as negative control by FBS. A positive control was also included in 3 wells. In the next day and after each step the plates were washed 3 times with washing buffer (phosphate buffer saline (PBS) and $0.05 \%$ tween 20). Also the plates were incubated at $37^{\circ} \mathrm{C}$ for one hour after each step. The plates were blocked with $200 \mu \mathrm{l} /$ well blocking buffer (PBS and 5\% skimmed milk). Sera samples were diluted as $1 / 40$ in diluting buffer (PBS, 0.5\% Skimmed milk and $0.05 \%$ tween 20) and loaded as duplicated. Peroxidase labeled anti bovine IgG 1:20000 (Bethyl laboratories, INC Germany) was used as $100 \mathrm{ml} /$ well. The substrate $(0.4 \mathrm{mg}$ o-phenylenediamine OPD and $0.4 \mu \mathrm{l}$ of $30 \% \mathrm{H}_{2} \mathrm{O}_{2}$ per $\mathrm{ml}$ of $0.01 \mathrm{M}$ citrate buffer $\mathrm{PH}$ 5) was added as $100 \mu \mathrm{l} /$ well. After color development the reaction stopped by 1:9 sulfuric acids in water and the optical density (OD) At (492) 
nm wavelength was read immediately after stopping the reaction with the stop solution.

\section{Cutoff endpoint calculation:}

By divided OD summation of the 3 negative control and 3 positive samples on the number 6 , the samples, which their OD above the cutoff endpoint was considered positive. While the samples, which their OD equal or lower than the cutoff endpoint was considered negative.

\section{Serum neutralization assay:}

A pool of infectious virus suspension was prepared, clarified and free aggregates by centrifugation. The aliquot of virus was diluted to obtain 100 TCID 50 per inoculum. The sera samples were heat inactivated at $56^{\circ} \mathrm{C}$ for $30 \mathrm{~min}$. Equal volume of serial dilution sera samples and100 TCID 50 virus suspension were mixed and incubated at $37^{\circ} \mathrm{C}$ for one hour. In 96 wells tissue culture plates $50 \mu \mathrm{l}$ of serum- virus mixture in each well was added. Cellular control and virus control were also included. A cellular suspension was prepared and added to all wells and the plates were incubated at $37^{\circ} \mathrm{C}$, $5 \% \mathrm{Co}_{2}$ with daily microscopic examination for cytopathic changes.

\section{RESULT}

1. The obtained result in virus and cell culture showed characteristic CPE of an international Mebus reference strain $72 \mathrm{hrs}$ post inoculation on MDBK cells as shown in (Fig.1\&2).

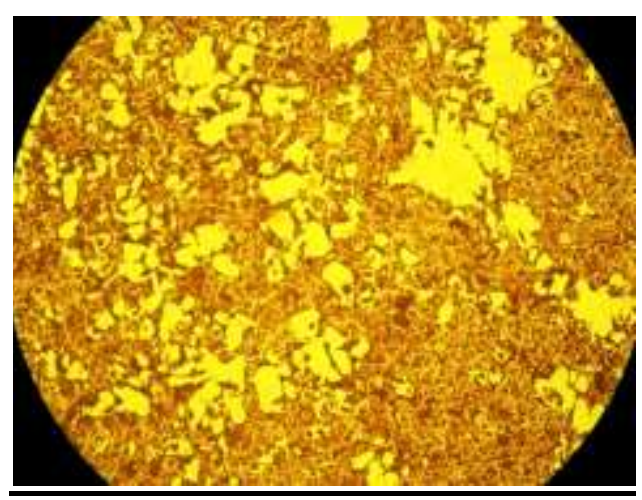

Fig. (1): CPE consisted of cell rounding, detachment, and complete monolayer destruction, 100x.



Fig. (2): CPE consisted of cell rounding, detachment, and complete monolayer destruction, 200x

\section{Concentration of $\mathrm{BCoV}$ antigen is 4.3} g/dl.

The results showed by Checkerboard titration finding for the prepared $\mathrm{BCoV}$ viral antigen and antibody optimization of ELISA are that the optimal amount of tissue culture polyethylene glycol concentration antigen coating level at $8 \mu \mathrm{g} /$ well and the working dilution in case of serum is 1:40. The Result of concentrated virus indicated that the major peak of the viral infectivity was found to be $8 \mu \mathrm{g} / \mathrm{well}$. At the 1:2000 dilution Conjugate was determined and used for the detection of $\mathrm{BCoV}$ antibodies using ELISA assay.

\section{Detection and titration of antibodies to $\mathrm{BCoV}$ in field serum sample using ELISA and SNT.}

The obtained results were as showed in table (1). 
Table 1: BCoV antibodies in calves serum by ELISA and SNT.

\begin{tabular}{lcc}
\hline & ELISA & SNT \\
\hline Positive & 47 & 35 \\
\hline Negative & 18 & 30 \\
\hline
\end{tabular}

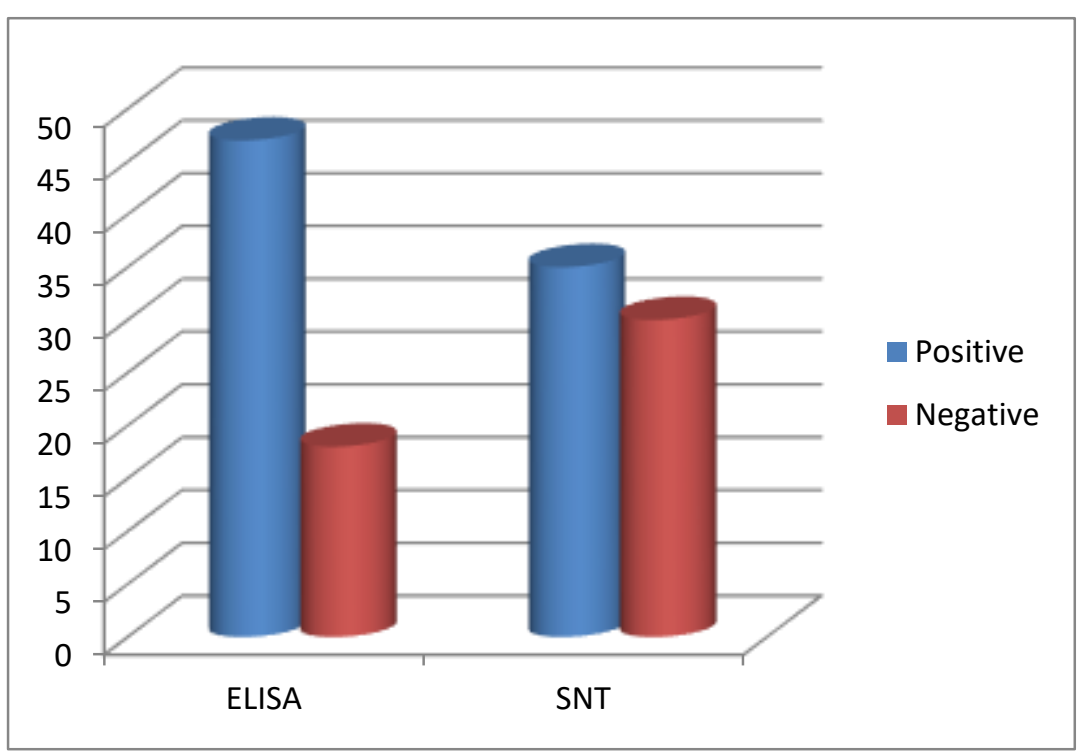

Fig. (3): Comparison between ELISA and SNT in detection of BCov antibodies

4. Determination of sensitivity, specificity and correlation of detection of $\mathrm{BCoV}$ antibodies by ELISA and SNT.

The results showed in table (2).

Table 2: BCoV antibodies sensitivity, specificity and correlation by ELISA and SNT

\begin{tabular}{cccc}
\hline \multirow{2}{*}{ ELISA } & \multicolumn{2}{c}{ SNT } & \multirow{2}{*}{ Total } \\
\cline { 2 - 3 } & Positive & Negative & 47 \\
\hline Positive & $32^{\mathrm{a}}$ & $15^{\mathrm{b}}$ & 18 \\
\hline Negative & $3^{\mathrm{c}}$ & $15^{\mathrm{d}}$ & 65 \\
\hline Total & 35 & 30 &
\end{tabular}

Sensitivity $=a /(a+c)=91.4 \%$.

Specificity $=\mathrm{d} /(\mathrm{b}+\mathrm{d})=50 \%$.

Correlation $=(\mathrm{a}+\mathrm{d}) /$ total $=72.3 \%$.

\section{DISCUSSION}

Newly born calves are an important source in livestock production worldwide for meat or breeding as replacement stock (Radostitis et al., 2007). BCoV is usually associated with the occurrence of diarrhea in calves and adult cattle, but it is also responsible for respiratory distress, being implicated as an etiological agent of bovine respiratory disease (BRD) (Bok et al.,
2015; Johnson and Pendell, 2017). Bovine respiratory disease is a complex multifactorial disease caused by multiple viruses such as BRSV, BoHV-1, BPIV-3 and BVDV. Also concurrent bacterial and mycoplasmal infections can exacerbate the course of viral diseases, increasing morbidity and mortality rates (Ha"gglund et al., 2007). The disease results in major economic losses in dairy herds that result from treatment costs and calf deaths (Sibel 
et al., 2016). Decaro et al. (2008), found in their study BRD occurred only in 2-3month-old calves as a result of a single $\mathrm{BCoV}$ infection without evidence of classical respiratory pathogens, such as BRSV, BoHV-1, and BVDV

Diagnosis of $\mathrm{BCoV}$ usually occurs by isolation of the virus or demonstration of an elevated serum antibodies titer. Because of time consuming of virus isolation methods, serum neutralization test and various ELISA are usually used for detection of antibodies against $\mathrm{BCoV}$ in enzootic regions and potentially respective extension zone (Lin et al., 2000). We aimed to prepare a highly sensitive antigen to be used as early diagnostic tools for detecting of specific BCoV antibody elevation. For this purpose, $\mathrm{BCoV}$ antigen was prepared by propagation of the virus in MDBK cell line and development of CPE 72 hrs postinoculation. The titer of the virus was $10^{6.4}$ TCID50. BCoV antigen was successfully prepared from reference Mebus $\mathrm{BCoV}$ strain by concentration with polyethylene glycol (PEG) 6000 used for examination of sera samples of cattle by ELISA technique. The result of concentrated virus indicated that the major peak of the viral infectivity was found to be $8 \mu \mathrm{g} / \mathrm{well}$. At the 1:2000 dilution, conjugate was determined and used for the detection of $\mathrm{BCoV}$ antibodies using ELISA assay. The same methodology was successfully used for preparing antigen by (Li et al., 2013).

The obtained results in virus and cell culture showed characteristic CPE of an international Mebus reference strain $72 \mathrm{hrs}$ post inoculation on MDBK cells CPE consisted of cell rounding, detachment, and complete monolayer destruction, (Fig.1\&2) these results agreed with that mentioned by (Saif et al., 1988) who successfully propagate $\mathrm{BCoV}$ at MDBK cells with high titres.

The results of indirect ELISA and SNT, respectively for detection of antibody titer in 65 bovine serum samples, Table (1), showed that 47 out of $65(72.3 \%)$ were positive for $\mathrm{BCoV}$ antibody detected by ELISA while only 35 out of 65 (53.9\%) detected by SNT. a total of 15 samples were positive by ELISA and negative by SNT. These results agreed with that mentioned by (Cho et al., 2001) who indicated approximately $90 \%$ of the worldwide cattle population has antibodies against $\mathrm{BCoV}$ and that $\mathrm{BCoV}$ antibodies-positive herds remained persistently high (75-100\%) (Ohlson et al., 2013). Also, (Clark, 1993) found that the $\mathrm{BCoV}$ prevalence in calves developing diarrhoea and clinically normal calves ranges from 8 to $69 \%$ and from 0 to $24 \%$, respectively. These results may be due to chronic virus shedding by affected animals (Ohlson et al., 2010b) who recorded nasal shedding within a herd form respiratory $\mathrm{BCoV}$ clinically or subclinically infected calves and young adult cattle. Shedding of BCoV in the absence of other important respiratory tract pathogens has been observed in cattle with naturally occurring BRD (Gomez et al., 2017).

Our results revealed high sensitivity of ELISA over SNT, where sensitivity, specificity and correlation were $91.4 \%$, $50 \%$ and $72.3 \%$ respectively, (Table 2). This was agreed by (Alenius et al., 1991) who concluded that ELISA is more sensitive than SNT in detection of antibodies in bovine sera. They expected that ELISA which detects antibodies against all viral components is more sensitive than SNT which detects only antibodies against viral neutralizing antigens, and observed that sera with high titer of antibody to BCoV by SNT had high titer by ELISA. Also, (Ohlson et al., 2010a) mentioned that one of the most important factors for using ELISA is its reliability for examination of serum samples with cytotoxic nature which cannot be examined by SNT. In addition to the indirect ELISA does not require any reagent which difficult to obtain or prepare. (Aspen, 2017) found $\mathrm{BCoV}$ ELISA was an effective procedure and simple technique yielded a high level of antigen and produced results at least 
equivalent to the standard SNT with considerable saving in time and labor cost.

The ELISA used to measure anti-BCoV antibodies in the present study detected total reactive rather than neutralizing antibodies. It is also possible that anti$\mathrm{BCoV}$ antibodies generated in response to a natural infection might have had a weak protective effect against viral replication, which would protect against the development of clinical signs of disease but not against virus shedding.

The study concluded that, the patent prepared ELISA is more sensitive, accurate and specific assay than SNT for detection of $\mathrm{BCoV}$ antibodies. Benefits to control programs include the test's ability to detect changes in antibody levels by analyzing paired samples and thereby identifying recent exposure to $\mathrm{BCoV}$, in addition to saving time and commercial kits cost.

\section{REFERENCES}

Alenius, S.; Niskanen, R.; Juntti, N. and Larsson, B. (1991): Bovine coronavirus as the causative agent of winter dysentery: serological evidence. Acta Veterinaria Scandinavica 32, 163-70.

Amer, H.M. (2019): Bovine-like coronaviruses in domestic and wild ruminants. Animal Health Research Reviews, 19, 113-124.https://doi.org/ 10.1017/S1466 252318000117

Ammar, S.S.; Mokhtaria, K.; Tahar, B.B.; Amar, A.A.; Redha, B.A.; Yuva, B.; Mohamed, H.S.; Abdellatif, N. and Laid, B. (2014): Prevalence of rotavirus (GARV) and coronavirus $(\mathrm{BCoV})$ associated with neonatal diarrhea in calves in western Algeria. Asian Pac J Trop Biomed. May; 4(Suppl1):S318-22. doi: 10.12980/ APJTB.4.2014C778. PMID: 25183104 ; PMCID: PMC4025335.

Aspen M. Workman; Larry A. Kuehn; Tara G. McDaneld; Michael L. Clawson;
Carol G. Chitko-McKown and John Dustin Loy (2017): Evaluation of the Effect of Serum Antibody Abundance against Bovine Coronavirus on Bovine Coronavirus Shedding and Risk of Respiratory Tract Disease in Beef Calves from Birth through the First Five Weeks in a Feedlot. AJVR (78) 9.

Bartels, C.J.M.; Holzhauer, M.; Jorritsma, R.; Swart, W.A. and Lam, T.J. (2010): Prevalence, prediction and risk factors of enteropathogens in normal and non-normal faeces of young Dutch dairy calves. Prev Vet Med. 93:162-169.

Boileau, M.J. and Kapil, S. (2010): Bovine coronavirus associated syndromes. Vet Clin North Am Food Anim Pract.; 26: 123-146. doi: 10.1016/ j.cvfa.2009.10.003. PMID: 20117547; PMCID: PMC7125561.

Bok, M.; Miño, S.; Rodriguez, D.; Badaracco, A.; Nuñes, I.; Souza, S.P. and Parreño, V. (2015): Molecular and antigenic characterization of bovine coronavirus circulating in argentinean cattle during 1994-2010. Veterinary Microbiology, 181(34):221-229. https://doi.org/10.1016/j. vetmic. 2015.10.017.

Bradford, M.M. (1976): A rapid and sensitive method for the quantitation of microgram quantities of protein utilizing the principle of protein-dye binding. Anal Biochem 72: 248- 254.

Cho, KO, Hoet, AE.; Loerch, SC.; Wittum, TE. and Saif, LJ.( 2001): Evaluation of concurrent shedding of Bovine coronavirus via the respiratory tract and enteric route in feedlot cattle. Am J Vet Res; 62: 1436-1441.

Clark, M.A. (1993): Bovine coronavirus. $\mathrm{Br}$ Vet J. Jan-Feb; 149(1): 51-70. doi: 10.1016/S0007-1935(05)80210-6.

PMID: 8382546; PMCID: PMC 7130254.

Decaro, N.; Mari. V.; Desario, C.; Campolo, M.; Elia, G.; Martella, V.; Greco, G.; Cirone, F.; Colaianni, M.L.; Cordioli, P. and Buonavoglia, 
C. (2008): Severe outbreak of bovine coronavirus infection in dairy cattle during the warmer season. Vet Microbiol.1; 126(1-3): 30-9. doi: 10.1016/j.vetmic. 2007.06.024. Epub 2007 Jun 28. PMID: 17669602; PMCID: PMC7117129.

Dunn, A.; Ashfield, A.; Earley, B.; Welsh, M.; Gordon, A.; McGee, M. and Morrison, S.J. (2017): Effect of concentrate supplementation during the dry period on colostrum quality and effect of colostrum feeding regimen on passive transfer of immunity, calf health, and performance. J Dairy Sci.; 100:357370. doi: 10.3168/jds.2016-11334. Epub 2016 Nov 17. PMID: 27865490.

Francoz, D.; Buczinski, S. and Bélanger, A.M. (2015): Respiratory pathogens in Québec dairy calves and their relationship with clinical status, lung consolidation, and average daily gain. J Vet Intern Med.; 29: 381-387.

Fulton, R.W. (2009): Bovine respiratory disease research (1983-2009). Anim Health Res Rev. 2009 Dec; 10(2): 131-139. doi: 10.1017/ S146625230999017X. PMID: 20003649

Gomez, DE.; Arroyo, LG.; Poljak, Z.; Viel, L.; and Weese, JS. (2017): Detection of Bovine Coronavirus in Healthy and Diarrheic Dairy Calves. J Vet Intern Med, 31(6):1884-1891. doi: 10.1111/ jvim.14811.

Hägglund, S.; Hjort, M.; Graham, D.A.; Ohagen, P.; Törnquist, $M$. and Alenius, S. (2007): A six-year study on respiratory viral infections in a bull testing facility. Vet J. 2007 May; 173(3): 585-593. doi: 10.1016/j.tvj1. 2006.02.010. PMID: 16647871; PMCID: PMC7110487.

Hasoksuz, M.; Vlasova, A. and Saif, L.J. (2008): Detection of group 2a coronaviruses with emphasis on bovine and wild ruminant strains. Virus isolation and detection of antibody, antigen, and nucleic acid. Methods Mol Biol.454: 43-59.

He, F. (2011): Bradford Protein Assay. Bio-101:e4.DOI: 10.21769/ BioProtoc. 45

Johnson, K.K. and Pendell, D.L. (2017): Market impacts of reducing the prevalence of bovine respiratory disease in United States beef cattle feedlots. Frontiers in Veterinary Science, 4, 189.

Lai, M.M.C. and Cavanagh, D. (1997): The molecular biology of coro- naviruses. Advances in Virus Research, 48(48), $1-100$. https://doi. org/10.1016/S0168-1702 (96)014219.

Lathrop, S.L.; Wittum, T.E.; Brock, K.V.; Loerch, S.C.; Perino, L.J.; Bingham, H.R.; McCollum, F.T. and Saif, L.J. (2000): Association between infection of the respiratory tract attributable to bovine coronavirus and health and growth performance of cattle in feedlots. Am J Vet Res. Sep; 61(9):1062-1066. doi:10.2460/ajvr. 2000.61.1062. PMID: 10976737.

Li, L.; Kantor, A. and Warne, N. (2013): Application of a PEG precipitation method for solubility screening: a tool for developing high protein concentration formulations. Protein Sci.; 22(8):1118-1123. doi:10.1002/ pro.2289.

Lin XQ.; O'Reilly KL. and Storz J. (2000): Antibody responses to respiratory coronavirus infections of cattle during shipping fever pathogenesis. Arch Virol 2000; 145: 2335-2349

Lin, X.Q.; O'Reilly, K.L. and Storz, J. (2002): Antibody responses of cattle with respiratory coronavirus infections during pathogenesis of shipping fever pneumonia are lower with antigens of enteric strains than with those of a respiratory strain. Clin Diagn Lab Immunol.9:1010-3.

Lotfollahzadeh, S.; Madadgar, O.; Reza Mohebbi, M.; Reza Mokhber Dezfouli, M. and George Watson, D. (2020): Bovine coronavirus in 
neonatal calf diarrhoea in Iran. Veterinary Medicine and Science, vms3.277. https://doi.org/10.1002/ vms3.277.

Mahy, B.W.J. and Kangro, H.O. (1996): Virology methods manual. London, Academic Press.

Mihai, I.G.; Kenneth, G.B.; Tony van, D.; Beverly, J.M.; Susy, M.A.; Rachel, A.S. and Jeff, L.C. (2006): Diseases and pathogens associated with mortality in Ontario beef feedlots. J Vet Diagn Invest 18:18-28.

Nylin, B.; Strøger, U. and Rønsholt, L. (2000): A retrospective evaluation of a Bovine Herpesvirus-1 (BHV-1) antibody ELISA on bulk-tank milk samples for classification of the BHV-1 status of Danish dairy herds. Preventive Veterinary Medicine Volume 47, Issues 1-2: 91-105.

Ohlson, A.; Alenius, S.; Traven, M. and Emanuelson, $\quad$ U. (2013): A longitudinal study of the dynamics of Bovine coronavirus and respiratory syncytial virus infections in dairy herds. Vet J. 197: 395-400.

Ohlson, A.; Tråvén, M.; Emanuelson, $U$. and Alenius, S. (2010a): A longitudinal study of the dynamics of bovine coronavirus and bovine respiratory syncytial virus infections in dairy herds in Ohlson, A. (2010): Bovine Coronoavirus and Bovine Respiratory Syncytial Virus Infections in Dairy Herds. Doctorate thesis 2010:51.

Ohlson, A.; Heuer, C.; Lockhart, C.; Tråvén, M.; Emanuelson, $U$. and Alenius, S. (2010b): Risk factors for seropositivity to bovine coronavirus and bovine respiratory syncytial virus in dairy herds. Veterinary Record 167, 201-6.

Oma, V.S.; Tråvén, M.; Alenius, S.; Myrmel, M. and Stokstad, M. (2016): Bovine coronavirus in naturally and experimentally exposed calves; viral shedding and the potential for transmission. Virology Journal 13: 100.
Radostits, O.M.; Gay, C.C.; Hinchcliff, K.W. and Constable, P.D. (2007): Veterinary Medicine: A Text book of disease of cattle, sheep, pigs, goats, and horses 10th edition, Ballier, Tindall, London. 49: 1523-1529

Reed, L.J. and Muench, H. (1938): A simple method of estimating fifty percent endpoints. The American Journal of Hygiene. 27: 493-497.

Reschová, S.; Pokorová, D.; Nevoránková, Z. and Franz, J. (2001): Monoclonal antibodies to bovine coronavirus and their use in enzymoimmunoanalysis and immunochromatography. Vet. Med. - Czech, 46, 2001 (5): 125-131.

Saif, L.J.; Heckert, R.A.; Miller, K.L. and Tarek, M.M. (1988): Cell culture propagation of bovine coronavirus. Journal of tissue culture methods, 11(3), 139-145. https://doi. org/10.1007/BF01404267

Sibel, Y.; Orhan, Y.; Mehmet, K.; Sima, S.; Faruk, P.; Metın, K.A. and Oguzhan, A. (2016): Bovine Coronavirus (BoCV) Infection in Calves with Diarrhoea and Their Dams. Acta Scientiae Veterinariae. 44: 1405.

Storz, J.; Lin, X.; Purdy, C.W.; Chouljenko, V.N.; Kousoulas, K.G.; Enright, F.M.; Gilmore, W.C.; Briggs, R.E. and Loan, R.W.(2000): Coronavirus and Pasteurella infections in bovine shipping fever pneumonia and Evans' criteria for causation. J Clin Microbiol. Sep; 38(9):3291-8. doi: 10.1128/JCM.38.9.3291-3298.2000.

PMID: 10970373 ; PMCID: PMC87376.

Yavru, S.; Yapici, $\quad$ O.; Kale, M.; Sahinduran, S.; Pehlivanoglu, F.; Albay, M.K. and Avci, O. (2018): Bovine coronavirus (BoCV) infection in calves with diarrhoea and their dams. Acta Scientiae Veterinariae, 44(1), 7. https://doi.org/10.22456/16799216.81176

Yoo, D. and Deregt, D. (2001): A single amino acid change within an- tigenic domain ii of the spike protein of 
bovine coronavirus confers resistance to virus neutralization. Clinical \& Diagnostic Laboratory Immunology,
8(2), 297. https://doi.org/10.1128/ CDLI.8.2.297-302.

\section{التثخيص السيرولوجى لفيروس الكورونا البقري في العجول باستخدام إليزا مطورة محليا

$$
\text { رانيا صلاح عبل الفتاح المحدي }
$$

E-mail: rania.elmohamdy@arc.sci.eg Assiut University web-site: www.aun.edu.eg

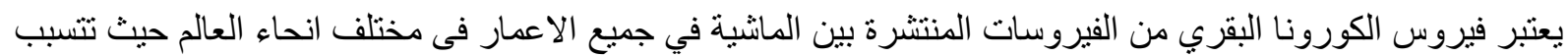

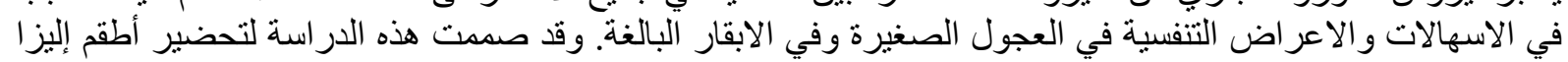

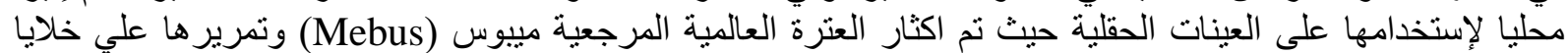

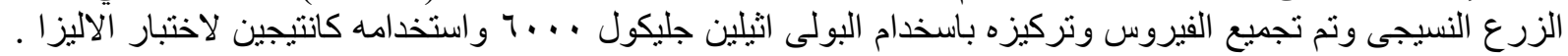



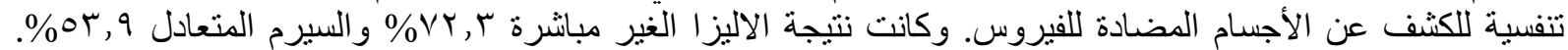

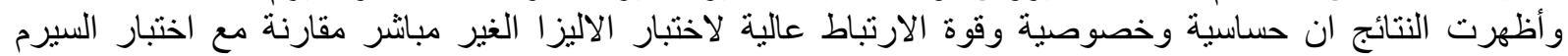

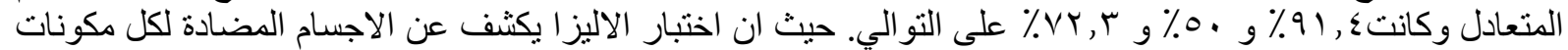

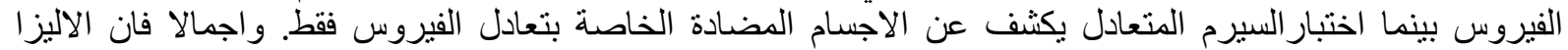

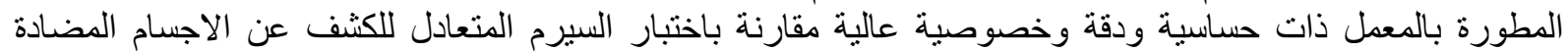
للفيروس كما انها نوفر الوقت وتكاليف استير ادها من الخارج. 